\title{
Vegetation-free Width and Irrigation Impact Peach Tree Growth, Fruit Yield, Fruit Size, and Incidence of Hemipteran Insect Damage
}

\author{
Connie L. Fisk ${ }^{1}$, Michael L. Parker ${ }^{2}$, and Wayne Mitchem \\ Department of Horticultural Science, North Carolina State University, \\ Campus Box 7609, Raleigh, NC 27695-7609
}

Additional index words. Prunus persica, orchard floor management, catfacing

\begin{abstract}
Orchard floor vegetation competes with peach trees for water and nutrients and may harbor pathogens and insects. Tree growth, fruit yield, and fruit size can be optimized through management of vegetation in the tree row and irrigation. Under-tree vegetation-free strip widths $(0,0.6,1.2,2.4,3.0$, and $3.6 \mathrm{~m})$ and irrigation were studied in years four through eight of a young peach orchard to determine their effects on peach tree growth and fruit yield, harvest maturity, and fruit size. Immature fruit samples were collected during thinning in years four through six to determine the effect of the treatments on the incidence of hemipteran (catfacing) insect damage. Trunk crosssectional area (TCSA), as a measure of tree growth, increased with increasing vegetationfree strip width; trees grown in the 3.6-m vegetation-free strip had TCSAs 2.2 times greater, on average, than trees grown in the $0-m$ vegetation-free strip. TCSA also increased with irrigation; trees grown with irrigation had TCSAs 1.2 times greater, on average, than trees grown without irrigation. Yield increased with increasing vegetationfree strip width, from $9.6 \mathrm{~kg}$ per tree in the $0-\mathrm{m}$ plot to $26.5 \mathrm{~kg}$ per tree in the $3.6-\mathrm{m}$ plot in year four, to $24.3 \mathrm{~kg}$ per tree in the $0-\mathrm{m}$ plot and $39.6 \mathrm{~kg}$ per tree in the $3.6-\mathrm{m}$ plot in year eight, for a total yield over years 4-8 per tree of $100 \mathrm{~kg}$ in the 0-m plot compared with $210 \mathrm{~kg}$ per tree in the 3.6-m plot. Yield, average fruit weight, and average fruit diameter increased with irrigation in three of 5 years; the other 2 years had higher than average rainfall reducing the need for supplemental irrigation. In 3 out of 5 years fruit in irrigated plots matured earlier than fruit in nonirrigated plots. In all years, fruit grown in the 0-m strip matured earliest and had the smallest diameter. Establishing a vegetationfree strip of as narrow as $0.6 \mathrm{~m}$ reduced the incidence of catfacing damage compared with the 0-m treatment, even though the orchard was on a commercial pesticide spray schedule. The least damage was seen with the industry standard vegetation-free strip widths greater than $3.0 \mathrm{~m}$ with or without irrigation.
\end{abstract}

Management of orchard floor vegetation is directly related to subsequent peach [Prunus persica (L.) Batsch] tree growth and yield (Arnold and Aldrich, 1980; Belding et al., 2004; Buckelew, 2009; Foy et al., 1994; Liverani et al., 1992; Majek et al., 1993; Meagher and Meyer, 1990; Welker and Glenn, 1989). Unwanted vegetation competes with trees for water and nutrients and can also serve as an alternate host for pathogens and insect pests, including hemipteran insects that damage and distort fruit, generally referred to as catfacing insects (Meagher et al., 1987; Meagher and Meyer, 1990; Mitchem, 2005).

Received for publication 12 Dec. 2014. Accepted for publication 24 Mar. 2015.

We thank Bernadette Clark and the staff at the Sandhills Research Station for their assistance with orchard management and sample collection, Robert Hoyt for herbicide applications, and Joy Smith for her assistance with statistical analyses.

${ }^{1}$ Current address: Southeast Research and Extension Center, University of Nebraska-Lincoln, 1071 County Road G, Ithaca, NE 68033-2234.

${ }^{2}$ To whom reprint requests should be addressed; e-mail mike_parker@ncsu.edu.
Orchard floor management strategies for peach production include establishing a cover crop or a permanent sod in the row middles to prevent erosion, maintain soil structure, and facilitate equipment movement during wet weather, with a vegetation-free strip in the tree row maintained with herbicides to maximize tree growth and productivity (Foy et al., 1994; Layne and Tan, 1988; Layne et al., 1994; Mitchem, 2005). Growth of young peach trees increases when grown in vegetation-free soil compared with trees grown with groundcover (Liverani et al., 1992; Meyer et al., 1992; Parker and Meyer, 1996). In peach orchards with vegetation in the row middles, growth increases as the width of the vegetation-free area in the tree row increases (Buckelew, 2009; Welker and Glenn, 1988; Welker and Glenn, 1989). A 3.0- to $3.6-\mathrm{m}$ wide vegetation-free strip in the tree row is a common orchard floor management system in the southeastern United States (Mitchem, 2005).

Supplemental irrigation of peach orchards is recommended in many locations with erratic precipitation and is especially encouraged on sandy soils. For drier climates or years, supplemental irrigation increases peach tree growth, fruit yield per tree, fruit size, and number of fruit buds per tree (due to greater shoot length) over nonirrigated trees (Buckelew, 2009; Layne and Tan, 1988; Layne et al., 1994; Reeder et al., 1979). The greater number of fruit buds per tree increases crop potential after a spring freeze. Water stress during the final fruit swell period (3-4 weeks preceding maturity) reduces fruit size and quality (Lockwood and Coston, 2005), and therefore economic returns. Drip irrigation from April or May through harvest in Georgia on Faceville and Greenville sandy loam soil was as effective at maximizing total yield and fruit diameter as irrigating all season (Horton et al., 1981). In Oklahoma on a Teller sandy loam there was no increase in either fruit yield or fruit size when irrigated from budbreak through harvest compared with only irrigating during the swell period (Huslig et al., 1993).

Significant insect damage to peach fruit in North Carolina is caused by a hemipteran complex which includes the tarnished plant bug, Lygus lineolaris (Palisot de Beauvois), and stink bugs in the genera Acrosternum, Euschistus, Nezara, and Thyanta (Killian and Meyer, 1984; Meyer and Ritchie, 1983) and is referred to as catfacing insect damage. These insects distort fruit shape with irregular and variable-sized necrotic skin spots and are managed using four to six early-season applications of broad-spectrum insecticides. However, even vigorous chemical applications in the southeastern United States will only provide partial control unless combined with an orchard floor vegetation management program (Meagher et al., 1987; Meyer, 1984). Vegetation management within and between rows can reduce the number of insecticide applications needed (Atanassov et al., 2002; Killian and Meyer, 1984). Insecticide-resistant populations of $L$. lineolaris have been reported (Snodgrass, 1996), thereby providing further support for integrated pest management strategies. Consumers are increasingly aware of and concerned about the amount of pesticide used in fruit production and their perceived effects on the environment (Flore, 1999). Reducing the amount of insecticide necessary to control catfacing insects would decrease inputs, minimize applicator risk, and reduce the potential for insecticide-resistant pest populations while possibly providing a marketing advantage for the product.

The objective of this study was to measure the effects of vegetation-free strip width and irrigation on peach tree growth, fruit yield, harvest maturity, size, and incidence of catfacing damage in a young (fourth to eighth leaf) peach orchard on a light sandy soil.

\section{Materials and Methods}

The experiment was conducted from 2009 to 2013 at the Sandhills Research Station in Jackson Springs, NC $\left(35.21^{\circ} \mathrm{N}, 79.63^{\circ} \mathrm{W}\right.$; average annual precipitation $117 \mathrm{~cm})$. Soil was a Candor sand (sandy, Koalinitic, thermic 
Grossarenic Kandiudults) with a pH of 5.8 and humic matter of $0.60 \%$. The orchard consisted of 'Contender' peach trees grafted onto 'Guardian ${ }^{\circledR}$ ' rootstock. One-year whips were planted on $3 \mathrm{Feb} .2006$ at a spacing of $5.5 \mathrm{~m}$ within the row and $6.0 \mathrm{~m}$ between rows. Trees were pruned each spring to an open center form (Lockwood and Myers, 2005).

The experimental design was a factorial randomized complete block with six replications and two factors, vegetation-free strip width $(0,0.6,1.2,2.4,3.0$, and $3.6 \mathrm{~m})$ with or without microsprinkler irrigation. Details of the treatments were described by Buckelew (2009). Each plot contained four trees, the two center trees being record trees. Vegetation-free strips were chemically maintained using Chateau ${ }^{\circledR}$ (flumioxazin at 213.3 g.ha ${ }^{-1}$ a.i.; Valent BioSciences Corp., Libertyville, IL) for preemergent weed control and Gramoxone Inteon ${ }^{\circledR}$ (paraquat at 0.67 to $1.0 \mathrm{~kg} \cdot \mathrm{ha}^{-1}$ a.i., with non-ionic surfactant at $0.25 \%(\mathrm{v} / \mathrm{v})$; Syngenta Crop Protection, LLC, Greensboro, NC) as a postemergent burndown. Row middles were allowed to populate with native weedy species and were maintained by mowing to a height of $10-13 \mathrm{~cm}$ tall. Insects were managed per the Southeastern Peach, Nectarine and Plum Pest Management and Culture Guide (Horton et al., 2013) using Imidan $^{\circledR}$ (phosmet at $3.36 \mathrm{~kg} \cdot \mathrm{ha}^{-1}$; Gowan, Yuma, AZ), Asana ${ }^{\circledR}$ (esfenvalerate at 0.8 $\mathrm{kg} \cdot \mathrm{ha}^{-1}$; DuPont, Wilmington, DE), Actara ${ }^{\circledR}$ (thiamethoxam at $0.28 \mathrm{~kg} \cdot \mathrm{ha}^{-1}$; Syngenta Crop Protection, LLC), and permethrin (0.56 $\mathrm{kg} \cdot \mathrm{ha}^{-1}$; Helena Chemical, Collierville, TN), all of which help control catfacing insects as well as other peach pests such as plum curculio and oriental fruit moth. All trees were fertilized uniformly with two applications of 20-0-20 each spring (224 kg.ha ${ }^{-1}$ in March and $168 \mathrm{~kg} \cdot \mathrm{ha}^{-1}$ in April).

For the irrigated plots, one Dan Modular microsprinkler (Jain Irrigation Inc., Fresno, CA) was placed $15 \mathrm{~cm}$ from the tree trunk on a $30 \mathrm{~cm}$ spray stake. Irrigated plots were irrigated as needed based on precipitation during the growing season. No irrigation was applied when precipitation during the week was $2.5 \mathrm{~cm}$ or greater (Table 1). The microsprinklers delivered $2.5 \mathrm{~cm}$ of water at each irrigation treatment in a 6.0-m diameter around the tree.

Trunk cross-sectional area (TCSA) was calculated from two perpendicular trunk diameter measurements taken $25 \mathrm{~cm}$ above the soil line during the dormant season.

Fruit thinning occurred each spring within $30-40 \mathrm{~d}$ of full bloom by hand so that remaining fruit were no closer than $15 \mathrm{~cm}$ apart. Fruit were thinned indiscriminately, whereas commercially a grower would selectively thin damaged fruit at this point. In 2009, all thinned fruit from one record tree in each plot were retained and examined for catfacing damage. In 2010 and 2011, a subsample of 200 thinned fruit from each two tree replication was retained and examined for catfacing damage. Results were converted to percentages for analysis.

Fruit were harvested over three or four dates each year. Fruit from each record tree were weighed for total yield and percentage
Table 1. Monthly weather data for the Sandhills Research Station, Jackson Springs, NC. ${ }^{\text {. }}$

\begin{tabular}{|c|c|c|c|c|c|}
\hline & 2009 & 2010 & 2011 & 2012 & 2013 \\
\hline \multicolumn{6}{|l|}{ March } \\
\hline Temperature $\min \left({ }^{\circ} \mathrm{C}\right)$ & 4.9 & 5.2 & 5.4 & 10.1 & 2.1 \\
\hline Temperature $\max \left({ }^{\circ} \mathrm{C}\right)$ & 15.6 & 16.9 & 16.7 & 22.0 & 13.7 \\
\hline Precipitation $(\mathrm{cm})$ & 10.2 & 12.1 & 11.3 & 15.9 & 8.3 \\
\hline Irrigation $(\mathrm{cm})$ & - & 0 & 0 & 0 & 0 \\
\hline \multicolumn{6}{|l|}{ April } \\
\hline Temperature $\min \left({ }^{\circ} \mathrm{C}\right)$ & 9.6 & 10.9 & 11.0 & 10.4 & 10.6 \\
\hline Temperature $\max \left({ }^{\circ} \mathrm{C}\right)$ & 22.6 & 24.7 & 23.5 & 22.0 & 22.0 \\
\hline Precipitation $(\mathrm{cm})$ & 4.3 & 2.8 & 10.2 & 11.3 & 17.6 \\
\hline Irrigation (cm) & - & 5.1 & 0 & 0 & 0 \\
\hline \multicolumn{6}{|l|}{ May } \\
\hline Temperature $\min \left({ }^{\circ} \mathrm{C}\right)$ & 15.4 & 16.6 & 15.3 & 16.5 & 14.0 \\
\hline Temperature $\max \left({ }^{\circ} \mathrm{C}\right)$ & 26.0 & 27.4 & 26.7 & 27.3 & 24.7 \\
\hline Precipitation $(\mathrm{cm})$ & 9.9 & 17.6 & 11.1 & 19.0 & 12.4 \\
\hline Irrigation (cm) & - & 2.5 & 0 & 0 & 0 \\
\hline \multicolumn{6}{|l|}{ June } \\
\hline Temperature $\min \left({ }^{\circ} \mathrm{C}\right)$ & 19.5 & 21.1 & 19.9 & 17.4 & 19.3 \\
\hline Temperature $\max \left({ }^{\circ} \mathrm{C}\right)$ & 30.1 & 32.4 & 32.6 & 29.4 & 28.9 \\
\hline Precipitation $(\mathrm{cm})$ & 6.1 & 8.9 & 10.0 & 10.3 & 36.0 \\
\hline Irrigation $(\mathrm{cm})$ & - & 7.6 & 10.2 & 0 & 0 \\
\hline \multicolumn{6}{|l|}{ July } \\
\hline Temperature $\min \left({ }^{\circ} \mathrm{C}\right)$ & 19.6 & 21.4 & 21.9 & 21.8 & 21.4 \\
\hline Temperature $\max \left({ }^{\circ} \mathrm{C}\right)$ & 30.2 & 32.4 & 33.5 & 32.7 & 29.7 \\
\hline Precipitation $(\mathrm{cm})$ & 14.0 & 27.9 & 14.2 & 42.4 & 46.3 \\
\hline Irrigation $(\mathrm{cm})$ & - & 5.1 & 5.1 & 2.5 & 0 \\
\hline
\end{tabular}

${ }^{\mathrm{z}}$ Temperature and precipitation data were obtained from the State Climate Office of North Carolina CRONOS Database (http://www.nc-climate.ncsu.edu/cronos/) for the weather station located at the Sandhills Research Station, Jackson Springs, NC.

$\tau_{-}=$Missing irrigation data from 2009.

Table 2. Effect of vegetation-free strip width and irrigation on trunk cross-sectional area $\left(\mathrm{cm}^{2}\right)$, years $4-8 .^{2}$

\begin{tabular}{lccccc}
\hline & \multicolumn{5}{c}{ Yr } \\
\cline { 2 - 6 } & 2009 & 2010 & 2011 & 2012 & 2013 \\
\cline { 2 - 6 } & \multicolumn{5}{c}{ Trunk cross-sectional area $\left(\mathrm{cm}^{2}\right)$} \\
\hline Strip width (m) & $22.8 \mathrm{~d}^{\mathrm{y}}$ & $32.8 \mathrm{~d}$ & $39.2 \mathrm{~d}$ & $47.0 \mathrm{~d}$ & $64.9 \mathrm{c}$ \\
0 & $38.7 \mathrm{c}$ & $49.6 \mathrm{c}$ & $57.6 \mathrm{c}$ & $66.3 \mathrm{c}$ & $85.8 \mathrm{~b}$ \\
0.6 & $45.7 \mathrm{bc}$ & $57.8 \mathrm{bc}$ & $66.4 \mathrm{bc}$ & $72.8 \mathrm{bc}$ & $91.7 \mathrm{~b}$ \\
1.2 & $54.1 \mathrm{ab}$ & $62.9 \mathrm{~b}$ & $72.6 \mathrm{~b}$ & $81.9 \mathrm{ab}$ & $102.7 \mathrm{ab}$ \\
2.4 & $50.0 \mathrm{~b}$ & $63.8 \mathrm{~b}$ & $73.5 \mathrm{ab}$ & $82.4 \mathrm{ab}$ & $99.5 \mathrm{ab}$ \\
3.0 & $62.6 \mathrm{a}$ & $75.7 \mathrm{a}$ & $88.0 \mathrm{a}$ & $96.3 \mathrm{a}$ & $115.5 \mathrm{a}$ \\
3.6 & $<0.0001$ & $<0.0001$ & $<0.0001$ & $<0.0001$ & $<0.0001$ \\
$P$ value & & & & & \\
Irrigation & & & & & \\
$\quad$ Irrigated & $51.9 \mathrm{a}$ & $63.1 \mathrm{a}$ & $70.8 \mathrm{a}$ & $80.3 \mathrm{a}$ & $97.6 \mathrm{a}$ \\
$\quad$ Nonirrigated & $39.4 \mathrm{~b}$ & $51.1 \mathrm{~b}$ & $61.6 \mathrm{~b}$ & $68.5 \mathrm{~b}$ & $89.1 \mathrm{~b}$ \\
$P$ value & $<0.0001$ & $<0.0001$ & 0.0021 & 0.0002 & 0.0373 \\
$P$ value for strip $\times$ irrigation interaction & 0.5065 & 0.8062 & 0.8661 & 0.9184 & 0.6707 \\
\hline
\end{tabular}

${ }^{\mathrm{z}}$ Main effect means are pooled across other main effects and 6 reps.

${ }^{y}$ Treatments were separated by the Tukey-Kramer method for each harvest date at the $P \leq 0.05$ level and means within each column within main effects followed by the same letter do not significantly differ.

Table 3. Effect of vegetation-free strip width and irrigation on peach yield $(\mathrm{kg})$, years $4-8{ }^{\mathrm{z}}$

\begin{tabular}{lllllll}
\hline & \multicolumn{7}{c}{ Yr } \\
\cline { 2 - 7 } & 2009 & 2010 & 2011 & 2012 & 2013 & Cumulative yield \\
\cline { 2 - 7 } & \multicolumn{7}{c}{ Peach yield $(\mathrm{kg})$} \\
\hline Strip width (m) & $9.6 \mathrm{e}^{\mathrm{y}}$ & $16.1 \mathrm{~d}$ & $21.7 \mathrm{~d}$ & $28.1 \mathrm{~d}$ & $24.3 \mathrm{~d}$ & $99.8 \mathrm{~d}$ \\
0 & $18.5 \mathrm{~cd}$ & $22.8 \mathrm{c}$ & $29.6 \mathrm{c}$ & $38.3 \mathrm{c}$ & $25.8 \mathrm{~cd}$ & $134.9 \mathrm{c}$ \\
0.6 & $17.1 \mathrm{~d}$ & $29.5 \mathrm{~b}$ & $34.6 \mathrm{bc}$ & $40.5 \mathrm{c}$ & $29.8 \mathrm{bc}$ & $151.4 \mathrm{c}$ \\
1.2 & $23.3 \mathrm{ab}$ & $31.8 \mathrm{~b}$ & $39.8 \mathrm{~b}$ & $49.1 \mathrm{ab}$ & $31.6 \mathrm{~b}$ & $175.7 \mathrm{~b}$ \\
2.4 & $21.6 \mathrm{bc}$ & $33.1 \mathrm{~b}$ & $39.9 \mathrm{~b}$ & $44.3 \mathrm{bc}$ & $37.0 \mathrm{a}$ & $175.9 \mathrm{~b}$ \\
3.0 & $26.5 \mathrm{a}$ & $43.2 \mathrm{a}$ & $46.7 \mathrm{a}$ & $54.2 \mathrm{a}$ & $39.6 \mathrm{a}$ & $210.2 \mathrm{a}$ \\
3.6 & $<0.0001$ & $<0.0001$ & $<0.0001$ & $<0.0001$ & $<0.0001$ & $<0.0001$ \\
$P$ value & & & & & & \\
Irrigation & $22.7 \mathrm{a}$ & $32.7 \mathrm{a}$ & $37.8 \mathrm{a}$ & 43.5 & 32.7 & $169.4 \mathrm{a}$ \\
$\quad$ Irrigated & $16.2 \mathrm{~b}$ & $26.1 \mathrm{~b}$ & $33.0 \mathrm{~b}$ & 41.3 & 30.0 & $146.6 \mathrm{~b}$ \\
$\quad$ Nonirrigated & $<0.0001$ & $<0.0001$ & 0.0020 & 0.2890 & 0.0571 & $<0.0001$ \\
$P$ value & & & & & & \\
$P$ value for strip $\times$ & 0.0759 & 0.5165 & 0.4302 & 0.4898 & 0.0798 & 0.2393 \\
$\quad$ irrigation interaction & 0.079 & \\
\hline
\end{tabular}

${ }^{\mathrm{z}}$ Main effect means are pooled across other main effects and 6 reps.

'Treatments were separated by Duncan's new multiple range test for each harvest date at the $P \leq 0.05$ level and means within each column within main effects followed by the same letter do not significantly differ. 
of total yield was calculated (tree yield for each date $\div$ by tree total yield $\times 100$ ) to determine differences in harvest maturity. Ten random fruit from each tree were weighed to calculate the average weight per fruit and measured for average fruit diameter.

Data were analyzed using SAS version 9.3 (SAS Institute Inc., Cary, NC). TCSA was analyzed using PROC MIXED with treatment means compared using the Tukey-Kramer method $(\alpha=0.05)$. The effects of vegetationfree strip width and irrigation on yield, harvest maturity, average fruit weight and diameter, and incidence of catfacing damage were analyzed using PROC GLM with treatment means compared using Duncan's new multiple range test $(\alpha=0.05)$. As these were young trees, and their production capacity had not yet plateaued, calculations were completed within a year and not across years. Catfacing incidence is likewise reported by year, as insect pressure varies by year.

\section{Results}

The effect of vegetation-free strip width and irrigation on TCSA is shown in Table 2. In all years, trees in the 0 -m vegetation-free strip width had the smallest TCSA, followed by trees in the $0.6-\mathrm{m}$ vegetation-free strip and the $1.2-\mathrm{m}$ strip, and trees in the 3.6-m strip had the greatest TCSA. Trees in the 2.4- and $3.0-\mathrm{m}$ vegetation-free strips had similar and intermediate TCSA measurements. Irrigated trees had a greater TCSA than nonirrigated trees, by $10.8 \mathrm{~cm}^{2}$ on average. There were no significant irrigation $\times$ strip width interactions in the 5 years studied.

The effect of vegetation-free strip width and irrigation on total yield is shown in Table 3. In all years, yield was greatest from trees with a 3.6-m vegetation-free strip and lowest from trees with a 0-m strip. Trees in the $0.6-3.0 \mathrm{~m}$ vegetation-free strips produced intermediate yields; trees with larger vegetation-free strips had greater yields compared with trees with smaller vegetation-free strips. Spring frost/ freeze blossom damage resulted in lower yields in 2013 with smaller treatment differences, although the trend was the same as in previous years. In 2009-11 irrigated trees had significantly greater yield, by an average of $6.0 \mathrm{~kg} /$ tree. Numerically greater yield also occurred with irrigation in 2012 and 2013, though the difference was not significant. There were no significant irrigation $\times$ strip width interactions in the 5 years studied.

The effect of vegetation-free strip width and irrigation on percent of total yield at each harvest date is shown in Table 4 and was used to determine if the vegetation-free strip width and/or irrigation altered the harvest date. In general, in most years, fruit grown in the $0 \mathrm{~m}$ strip width matured earliest with the greatest percentage of total yield at the first harvest and fruit grown in the 3.6-m strip had the lowest percentage of total yield at the first harvest. Trees grown in the 0.6$3.0 \mathrm{~m}$ vegetation-free strips demonstrated intermediate maturity dates. In 2011 and 2012 , percentage of total yield on the second

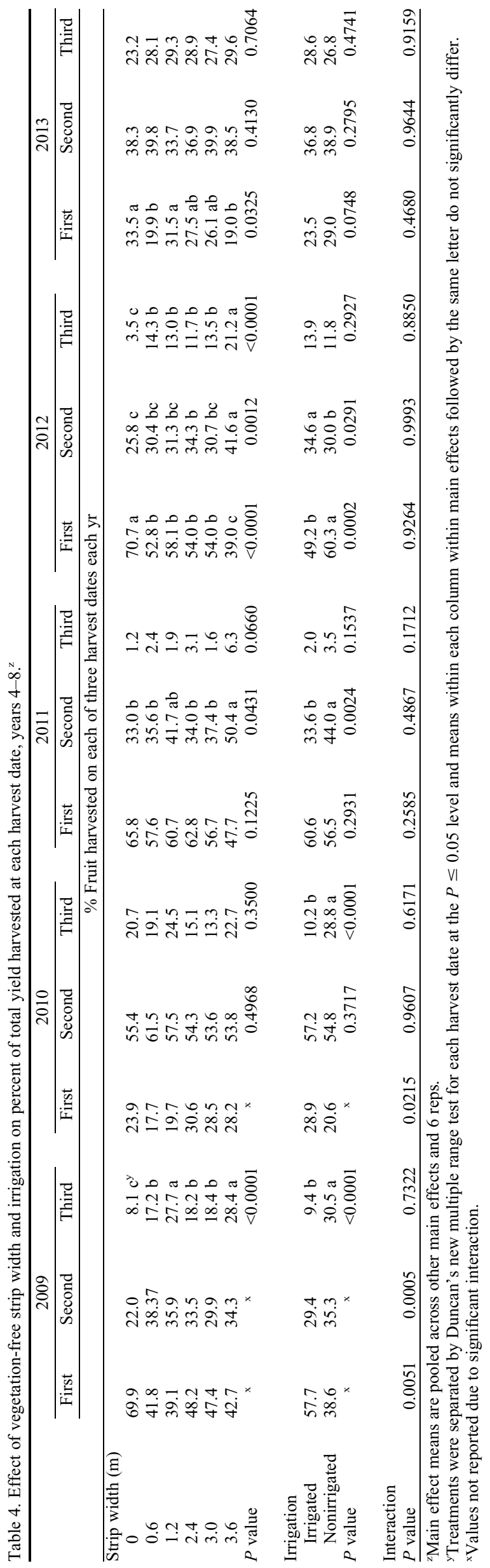


harvest date increased with greater vegetationfree strip widths. In 2009 and 2012, the 3.6-m vegetation-free strip width treatment had the greatest and the $0-\mathrm{m}$ plot had the lowest percentage of total yield collected at the third harvest. This same trend was also seen in 2011, though not statistically significant $(P=0.07)$.

There were differences in maturity on the first harvest date due to irrigation; in 2012, fruit in nonirrigated plots ripened earlier than fruit grown in irrigated plots. In 2011 and 2013, there was no significant difference between irrigated and nonirrigated plots for maturity at the first harvest. In 2011, irrigated treatments had a smaller percentage of total yield collected on the second harvest date compared with nonirrigated treatments while in 2012 irrigated treatments had a greater percentage of total yield collected on the second harvest date compared with nonirrigated treatments. Nonirrigated treatments had a greater percentage of total harvest collected on the third harvest date than irrigated treatments in 2009 and 2010, with no significant differences due to irrigation in years 2011-13.

There were significant irrigation $\times$ strip width interactions for maturity at the first harvest in two of the 5 years studied (Fig. 1) and at the second harvest in one of the 5 years studied. Trees in the nonirrigated 1.2- and 2.4-m vegetation-free strips had percentages of total yield at the first harvest that differed from the expected trend based on the other treatments. There were no significant strip $x$ irrigation interactions for percentage of total yield collected on the third harvest date in the 5 years studied.

The effect of vegetation-free strip width and irrigation on average peach weight is shown in Table 5. In 2009 and 2010 fruit grown in the 3.0and 3.6-m vegetation-free strips had the greatest average weight followed by fruit from the 1.2and 2.4-m vegetation-free strips. Fruit grown in the 0 -m strip were among the lowest weights in three out of 5 years. In years 2009-11, fruit were larger in irrigated vs. nonirrigated plots, with an average increase of $19 \%$, while in 2012 fruit were larger in nonirrigated plots than in irrigated plots, by $8 \%$. There was a slight $(P=$ $0.0496)$ irrigation $\times$ strip width interaction in 2013.

The effect of vegetation-free strip width and irrigation on average peach diameter is shown in Table 6. Increasing vegetation-free strip width significantly increased fruit diameter in 2009, 2010, and 2013. In all years, fruit grown in the 0-m strip had the smallest diameter, although not significantly so in 2011 and 2012. Irrigation increased fruit diameter in years 2009-11, with an average increase of $7 \%$, and appeared to slightly decrease diameter in 2012 and 2013, by an average of $1 \%$, though the irrigation was only turned on once in 2012 and not at all in 2013. There were no significant irrigation $\times$ strip width interactions in the 5 years studied.

The effect of vegetation-free strip width and irrigation on the incidence of catfacing damage is shown in Table 7. In 2009 and 2011, the highest incidence of catfacing damage occurred in the $0-\mathrm{m}$ treatment and

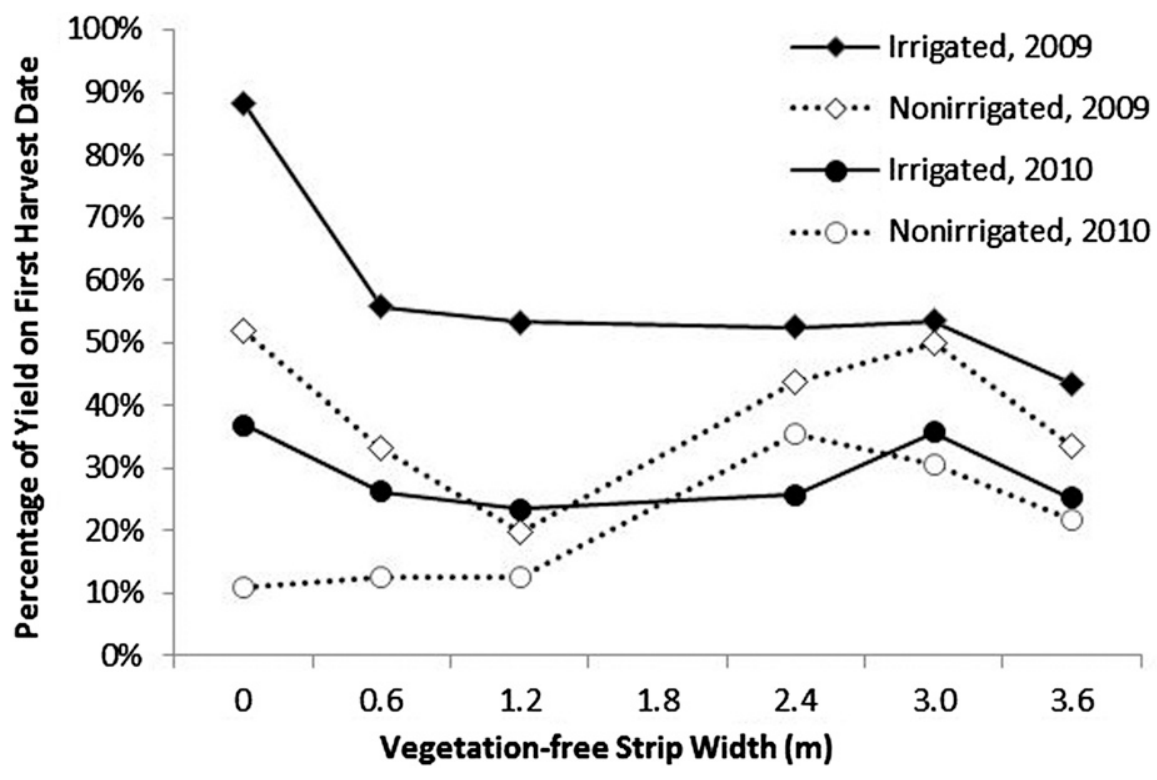

Fig. 1. Interaction between vegetation-free strip width and irrigation on the maturity at first harvest of peach, years 4-5.

Table 5. Effect of vegetation-free strip width and irrigation on average peach weight (g), years 4-8.

\begin{tabular}{|c|c|c|c|c|c|}
\hline & \multicolumn{5}{|c|}{$\mathrm{Yr}$} \\
\hline & 2009 & 2010 & 2011 & 2012 & 2013 \\
\hline & \multicolumn{5}{|c|}{ Avg peach wt (g) } \\
\hline \multicolumn{6}{|l|}{ Strip width (m) } \\
\hline 0 & $169.9 \mathrm{~b}^{\mathrm{y}}$ & $133.6 \mathrm{~d}$ & 185.3 & 185.6 & 196.1 \\
\hline 0.6 & $166.8 \mathrm{~b}$ & $147.5 \mathrm{c}$ & 182.6 & 205.4 & 201.6 \\
\hline 1.2 & $176.7 \mathrm{ab}$ & $151.8 \mathrm{bc}$ & 183.0 & 185.4 & 204.1 \\
\hline 2.4 & $178.8 \mathrm{ab}$ & $156.2 \mathrm{bc}$ & 193.7 & 189.8 & 222.2 \\
\hline 3.0 & $193.1 \mathrm{a}$ & $163.4 \mathrm{ab}$ & 193.0 & 197.2 & 210.3 \\
\hline 3.6 & $191.5 \mathrm{a}$ & $172.0 \mathrm{a}$ & 186.7 & 190.7 & 220.9 \\
\hline$P$ value & 0.0041 & $<0.0001$ & 0.1531 & 0.0795 & $\mathrm{x}$ \\
\hline \multicolumn{6}{|l|}{ Irrigation } \\
\hline Irrigated & $202.8 \mathrm{a}$ & $165.0 \mathrm{a}$ & $199.7 \mathrm{a}$ & $185.1 \mathrm{~b}$ & 203.8 \\
\hline Nonirrigated & $155.8 \mathrm{~b}$ & $143.1 \mathrm{~b}$ & $175.0 \mathrm{~b}$ & $199.6 \mathrm{a}$ & 214.6 \\
\hline$P$ value & $<0.0001$ & $<0.0001$ & $<0.0001$ & 0.0014 & $\mathrm{x}$ \\
\hline $\begin{array}{l}P \text { value for strip } \times \text { irrigation } \\
\text { interaction }\end{array}$ & 0.7042 & 0.7782 & 0.3129 & 0.2088 & 0.0496 \\
\hline
\end{tabular}

${ }^{\mathrm{z}}$ Main effect means are pooled across other main effects and 6 reps.

yTreatments were separated by Duncan's new multiple range test for each harvest date at the $P \leq 0.05$ level and means within each column within main effects followed by the same letter do not significantly differ. ${ }^{\mathrm{x}}$ Values not reported due to significant interaction.

Table 6. Effect of vegetation-free strip width and irrigation on average peach diameter (cm), years $4-8{ }^{2}$

\begin{tabular}{lccccc}
\hline & \multicolumn{5}{c}{ Yr } \\
\cline { 2 - 6 } & 2009 & 2010 & 2011 & 2012 & 2013 \\
\cline { 2 - 6 } & \multicolumn{5}{c}{ Avg peach diam $(\mathrm{cm})$} \\
\hline Strip width (m) & $6.6 \mathrm{c}$ & $6.3 \mathrm{~d}$ & 6.9 & 6.8 & $7.2 \mathrm{c}$ \\
0 & $6.7 \mathrm{bc}$ & $6.4 \mathrm{~cd}$ & 6.9 & 7.0 & $7.3 \mathrm{bc}$ \\
0.6 & $6.9 \mathrm{~b}$ & $6.5 \mathrm{bc}$ & 7.0 & 6.9 & $7.3 \mathrm{bc}$ \\
1.2 & $6.9 \mathrm{~b}$ & $6.6 \mathrm{bc}$ & 7.1 & 7.0 & $7.5 \mathrm{a}$ \\
2.4 & $7.1 \mathrm{a}$ & $6.7 \mathrm{ab}$ & 7.1 & 7.0 & $7.4 \mathrm{ab}$ \\
3.0 & $7.1 \mathrm{a}$ & $6.8 \mathrm{a}$ & 7.0 & 7.0 & $7.5 \mathrm{a}$ \\
3.6 & $<0.0001$ & $<0.0001$ & 0.0688 & 0.2340 & $<0.0001$ \\
$P$ value & & & & \\
Irrigation & $7.2 \mathrm{a}$ & $6.7 \mathrm{a}$ & $7.1 \mathrm{a}$ & $6.9 \mathrm{~b}$ & $7.3 \mathrm{~b}$ \\
$\quad$ Irrigated & $6.5 \mathrm{~b}$ & $6.4 \mathrm{~b}$ & $6.8 \mathrm{~b}$ & $7.0 \mathrm{a}$ & $7.4 \mathrm{a}$ \\
$\quad$ Nonirrigated & $<0.0001$ & $<0.0001$ & $<0.0001$ & 0.0138 & 0.0013 \\
$P$ value & 0.3431 & 0.9620 & 0.1002 & 0.3149 & 0.1261 \\
$P$ value for strip $\times$ irrigation interaction & &
\end{tabular}

${ }^{\mathrm{z}}$ Main effect means are pooled across other main effects and 6 reps.

y Treatments were separated by Duncan's new multiple range test for each harvest date at the $P \leq 0.05$ level and means within each column within main effects followed by the same letter do not significantly differ. 
Table 7. Effect of vegetation-free strip width and irrigation on percent catfacing damage in 'Contender' peach, years $4-6 .^{2}$

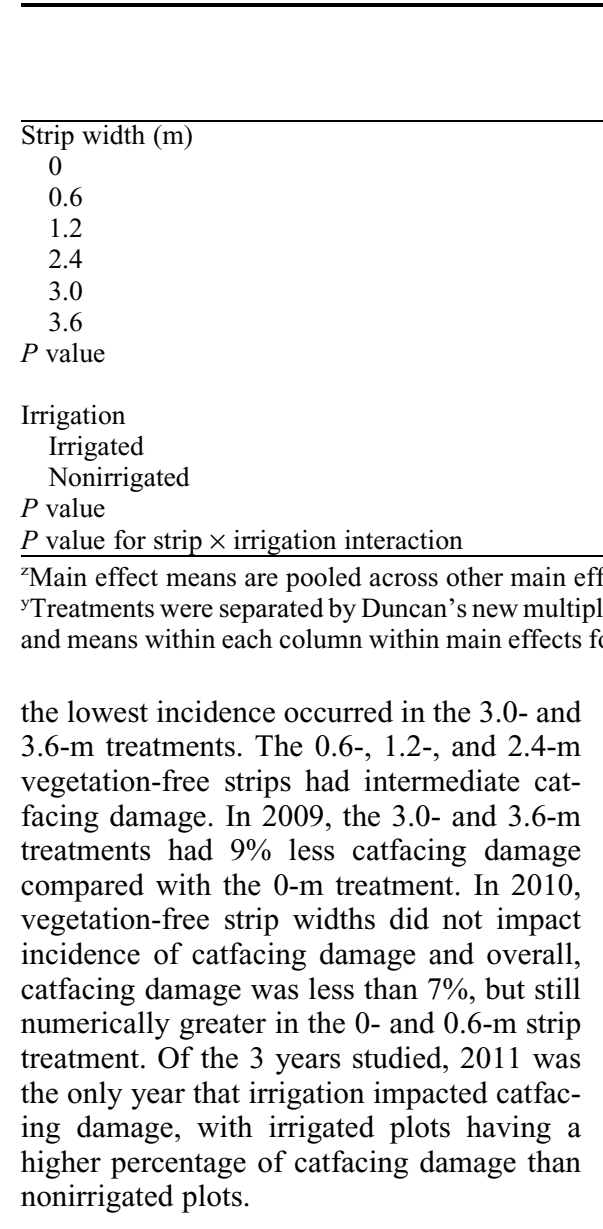

\section{Discussion}

This work focused on peach trees in years 4 8 , with vegetation-free strip width and irrigation treatments that were initiated at planting, and demonstrates that increasing the vegetation-free strip width under the trees results in greater tree growth and greater yield, in agreement with other studies on younger trees (Arnold and Aldrich, 1980; Belding et al., 2004; Buckelew, 2009; Foy et al., 1994; Liverani et al., 1992; Majek et al., 1993; Welker and Glenn, 1989). In this study, we have shown that to also be the case on light sandy soils and we evaluated the impact of irrigation to overcome any adverse effects of the vegetative competition. In years 4-7 (200912 , Table 2), across strip width treatments, tree growth in the nonirrigated plots was at least 1 year behind trees grown in irrigated plots. Yields in the eighth year (2013) were lower due to frost/ freeze damage in the spring, but fruit size was greater. Annual yield increased, on average, by $23.4 \mathrm{~kg} /$ tree between the irrigated $0-\mathrm{m}$ and 3.6-m vegetation-free strip width plots, and 20.8 $\mathrm{kg} /$ tree between the nonirrigated $0-\mathrm{m}$ and 3.6-m vegetation-free strip width plots (data not shown). Assuming an expected price of US\$24 per $23 \mathrm{~kg}$ (M.L. Parker, personal communication) and an average of 299 trees per hectare at a $5.5 \times 6.0 \mathrm{~m}$ spacing (Lockwood and Myers, 2005), maintaining a 3.6-m vegetation-free strip could increase gross per hectare income by US $\$ 7176$ annually.
Results show that fruit grown with wider vegetation-free strip widths may ripen over a longer period than fruit grown with narrower vegetation-free strip widths. The first and last harvest dates differed by only 7-9 d each year. Although the difference in harvest maturity between $0-\mathrm{m}$ and $3.6-\mathrm{m}$ vegetationfree strip width plots on the first harvest date each year may not be great enough in all years to be useful for targeted volume prediction, it may offer a simple and useful variable for offsetting rainfall losses or staggering harvests.

Welker and Glenn (1989) reported that the percentage of large fruit (greater than $7.0 \mathrm{~cm}$ ) increased as the size of the vegetation-free area increased. We observed a trend for greater individual fruit weight and diameter with increasing vegetation-free strip width, with the 3.0- and 3.6- $\mathrm{m}$ vegetation-free strip widths each producing fruit greater than or equal to $7.0 \mathrm{~cm}$ in diameter in four out of 5 years. In 2013, fruit from all strip widths were greater than $7.0 \mathrm{~cm}$, likely due to the above average rainfall that year as well as reduced crop load due to frost/freeze damage (Table 1).

Supplemental irrigation did increase tree growth and fruit yield on sandy soil, in agreement with other studies on heavier soils (Layne and Tan, 1988; Layne et al., 1994; Reeder et al., 1979). The earlier fruit ripening and greater average weight and diameter in years of average rainfall (2009-11) further indicate a commercial need and benefit of irrigation for peach on sandy soil, even in an area with relatively high annual rainfall.

Buckelew (2009), observing newly planted and younger trees in the same orchard as this study, reported that peach yields in the third year of a nonirrigated $3.6-\mathrm{m}$ vegetation-free strip could be matched by using irrigation in a vegetation-free strip of $1.2 \mathrm{~m}$. However, in the years observed in the current study, the use of irrigation in vegetation-free strips of 1.2 $3.0 \mathrm{~m}$ was not sufficient to match the yield produced in a nonirrigated $3.6-\mathrm{m}$ vegetationfree strip. Reducing the vegetation-free area will increase the amount of soil surface covered with vegetation, contributing soil organic mat- ter, maintaining soil structure, and reducing erosion, measures positively related to the agricultural productivity of a site. Reducing the width of the vegetation-free strip will also reduce the amount of herbicide growers need to apply each year, reducing input costs. However, the long-term impact on annual yield, fruit size and weight may make this practice unacceptable, especially in areas where irrigation is not practical due to water scarcity and cost.

Killian and Meyer (1984) reported a reduction in the incidence of catfacing damage on peaches with herbicide control of winter annual weeds in the tree row ( $2 \%$ damage with treatment compared with $14 \%$ without) or over the entire orchard floor (4\% damage with treatment compared with $9 \%$ without). Our results indicate that benefits can be seen with a vegetation-free strip under the tree (eliminating all weeds, not just winter annuals) as narrow as $0.6 \mathrm{~m}$, potentially reducing the amount of insecticide that will need to be sprayed each year. These differences were observed in an orchard where a commercial pest management program was in place. The use of a vegetation-free strip in the tree row will certainly not eliminate the need for insecticide sprays but will make them more effective.

Although the orchard used in the present study was on a commercial pest management schedule, there was still a reduction in catfacing damage by increasing vegetation-free strip widths. Using 2009 data, if we assume an average yield of $20,000 \mathrm{~kg} \cdot \mathrm{h}^{-1}$ and an expected price of US\$24 per $23 \mathrm{~kg}$ (M.L. Parker, personal communication), an average $9 \%$ increase in saleable yield would produce an additional $1800 \mathrm{~kg}$ of fruit worth US\$1878 per hectare annually. This increase in saleable yield would more than offset the cost of herbicides necessary to maintain the vegetation-free strip in addition to the yield and fruit size benefits.

The catfacing data were collected in years 4-6. As the trees age and the canopy diameter increases, a wider vegetation-free strip may be required to minimize catfacing damage and maximize orchard profitability. The interaction between irrigation $\times$ strip width needs further exploration to determine the optimum vegetation-free strip width and irrigation for maximum fruit yield and quality. It is also important to note that only one peach variety, 'Contender', was used in this study. 'Contender' has a very high blossom density; the benefit of catfacing reduction may be greater on varieties with a lower bloom density, as growers remove fewer fruit at thinning and proportional loss of marketable fruit will cause higher economic losses.

\section{Literature Cited}

Arnold, M.E. and J.H. Aldrich. 1980. Herbicidal effects on peach seedling growth and weed control. HortScience 15:293-294.

Atanassov, A., P.W. Shearer, G. Hamilton, and D. Polk. 2002. Development and implementation of a reduced risk peach arthropod management program in New Jersey. J. Econ. Entomol. 95:803-812. 
Belding, R.D., B.A. Majek, G.R.W. Lokaj, J. Hammerstedt, and A.O. Ayeni. 2004. Orchard floor management influence on summer annual weeds and young peach tree performance. Weed Technol. 18:215-222.

Buckelew, J.K. 2009. Orchard floor management in young peach [Prunus persica (L.) Batch.]: Effects of irrigation, vegetation-free width, and certain PRE herbicides. NC State Univ., Raleigh, NC, Ph.D. Diss.

Flore, J.A. 1999. Reduced chemical input production of peach. SARE in Michigan, Michigan State University Extension Bulletin E 2692:2-3.

Foy, C.L., S.B. Harrison, and H.L. Witt. 1994. Herbicide effects on weed control and shoot growth of young apple (Malus sylvestris) and peach (Prunus persica) trees. Weed Technol. 8:840-848.

Horton, B.D., E.J. Wehunt, J.H. Edwards, R.R. Bruce, and J.L. Chesnee. 1981. The effects of drip irrigation and soil fumigation on 'Redglobe' peach yields and growth. J. Amer. Soc. Hort. Sci. 106:438-443.

Horton, D., P. Brannen, B. Bellinger, D. Lockwood, and D. Ritchie (eds.). 2013. 2013 Southeastern Peach, Nectarine and Plum Pest Management and Culture Guide. 27 June 2013. <http://www. ent.uga.edu/peach/peachguide.pdf $>$.

Huslig, S.M., M.W. Smith, and G.H. Brusewitz. 1993. Irrigation schedules and annual ryegrass as a ground cover to conserve water and control peach tree growth. HortScience 28:908-913.

Killian, J.C. and J.R. Meyer. 1984. Effect of orchard weed management on catfacing damage to peaches in North Carolina. J. Econ. Entomol. 77:1596-1600.
Layne, R.E.C. and C.S. Tan. 1988. Influence of cultivars, ground covers, and trickle irrigation on early growth, yield, and cold hardiness of peaches on Fox sand. J. Amer. Soc. Hort. Sci. 113:518-525.

Layne, R.E.C., C.S. Tan, and D.M. Hunter. 1994 Cultivar, ground-cover, and irrigation treatments and their interactions affect long-term performance of peach trees. J. Amer. Soc. Hort. Sci. 119:12-19.

Liverani, A., D. Cobianchi, A. Crociani, and D. Missere. 1992. Effect of soil management systems on hillside peach orchards. Acta Hort. 315:123-127.

Lockwood, D.W. and D.C. Coston. 2005. Peach tree physiology, p. 5-10. In: D. Horton and D. Johnson (eds.). Southeastern peach growers' handbook. Georgia Experiment Station Handbook No. 1. University of Georgia, Athens, GA.

Lockwood, D.W. and S.C. Myers. 2005. Tree density, orchard design, and training systems, p. 51-64. In: D. Horton and D. Johnson (eds.). Southeastern peach growers' handbook. Georgia Experiment Station Handbook No. 1. University of Georgia, Athens, GA.

Majek, B.A., P.E. Neary, and D.F. Polk. 1993. Smooth pigweed interference in newly planted peach trees. J. Prod. Agr. 6:244-246.

Meagher, R.L. and J.R. Meyer. 1990. Effects of ground cover management on certain abiotic and biotic interactions in peach orchard ecosystems. Crop Prot. 9:65-72.

Meagher, R.L., J.R. Meyer, and J.C. Killian. 1987. Within-tree distribution of cat-facing injury on peaches in North Carolina. J. Agr. Entomol. 4:78-81.
Meyer, J.R. 1984. Catfacing in peaches: Effects of ground cover and surrounding vegetation. Proc. Joint Natl. Peach Counc. Southeast Peach Conven. 5-11.

Meyer, J.R. and D.F. Ritchie. 1983. Peach diseases and insects in North Carolina. NC Agric. Ext. Ser. AG-146.

Meyer, J.R., E.I. Zehr, R.L. Meagher, Jr., and S.K. Salvo. 1992. Survival and growth of peach trees and pest populations in orchard plots managed with experimental ground covers. Agr. Ecosyst. Environ. 41:353-363.

Mitchem, W.E. 2005. Weed management considerations for peach orchards, p. 279-284. In: D. Horton and D. Johnson (eds.). Southeastern peach growers' handbook. Georgia Experiment Station Handbook No. 1. University of Georgia, Athens, GA.

Parker, M.L. and J.R. Meyer. 1996. Peach tree vegetative and root growth respond to orchard floor management. HortScience 31:330-333.

Reeder, B.D., J.S. Newman, and J.W. Worthington. 1979. Effect of trickle irrigation on peach trees. HortScience 14:36-37.

Snodgrass, G.L. 1996. Insecticide resistance in field populations of the tarnished plant bug (Heteroptera: Miridae) in cotton in the Mississippi Delta. J. Econ. Entomol. 89:783-790.

Welker, W.V. and D.M. Glenn. 1988. Growth suppression of peach trees with competition. Proc. Annu. Meet. Northeast. Weed Sci. Soc. 42:243.

Welker, W.V. and D.M. Glenn. 1989. Sod proximity influences the growth and yield of young peach trees. J. Amer. Soc. Hort. Sci. 114:856-859. 